\title{
PENGARUH VISUAL MERCHANDISING, ATMOSFER TOKO, DAN DISPLAY PRODUK TERHADAP IMPULSE BUYING PELANGGAN RAMAYANA DENPASAR
}

\author{
I Kadek Dian Kertiana ${ }^{1}$ \\ I Gst. A. Kt. Sri Artini \\ ${ }^{1,2}$ Fakultas Ekonomi dan Bisnis, Universitas Udayana (Unud), Bali, Indonesia \\ email: raydian07@gmail.com
}

\begin{abstract}
ABSTRAK
Tujuan penelitian ini adalah untuk mengetahui pengaruh visual merchandising, atmosfer toko, dan display produk terhadap impulse buying.Penelitian ini di lakukan di Ramayana department store, Jl. Diponegoro No. 103 Denpasar, Bali. Teknik pengambilan sampel penelitian ini adalah non probability samplingdan purposive samplingsebanyak 100 responden. Teknik analisis menggunakananalisis regresi linier berganda.Hasil analisis data menunjukkan bahwa kegiatan visual merchandising berpengaruh negatif dan tidak signifikan terhadap impulse buying. Atmosfer toko berpengaruh negatif dan tidak signifikan terhadap impulse buying. display produk berpengaruh positif namun tidak signifikan terhadap impulse buying. Hasil penelitian ini diharapkan dapat digunakan oleh pebisnis ritel dan manajemen produk Ramayana department store dalam menyusun strategi, variabel visual merchandising, atmosfer toko dan display produk telah terbukti dua dari tiga variabel tersebut memiliki dampak tidak signifikan terhadap pembelian impulse. Variabel lain perlu dipertimbangkan sehingga dapat mengoptimalkan impulse buying dan omzet perusahaan. Kata kunci:Impulse buying, visual merchandising, atmosfer toko, display produk.
\end{abstract}

\begin{abstract}
The purpose of this study was to determine the effect of visual merchandising, store atmosphere, and product display on impulse buying. This research was conducted at Ramayana department store, Jl. Diponegoro No. 103 Denpasar, Bali. The sampling technique of this study was $100 \%$ non-probability sampling and purposive sampling. The analysis technique uses multiple linear regression analysis. The results of data analysis showed that visual merchandising activities had a negative and insignificant effect on impulse buying. The store's atmosphere has a negative and not significant effect on impulse buying. product display has a positive but not significant effect on impulse buying. The results of this study are expected to be used by retail business and department store Ramayana product management in developing strategies, visual merchandising variables, store atmosphere and product displays. It has been proven that two of the three variables have no significant impact on impulse purchases. Other variables need to be considered so as to optimize the impulse buying and turnover of the company.
\end{abstract}

Keywords: Impulse buying, visual merchandising, store atmosphere, product display. 


\section{PENDAHULUAN}

Perkembangan bisnis ritel di Indonesia terus mengalami kenaikan tiap tahunnya.Pesatnya perkembangan ritel modern ini didasarkan pada keinginan perusahaan untuk memenuhi kebutuhan pelanggannya.Bisnis ritelmerupakan semua kegiatan penjualan barang dan jasa secara langsung kepada konsumen akhir untuk pemakaian pribadi dan rumah tangga, bukan untuk keperluan bisnis.

Bisnis ritel di Indonesia digolongkan berdasarkansifatnya, yaitu ritel yang bersifattradisional atau konvensional dan yangbersifat modern. Ritel yang bersifattradisional adalah sejumlah pengecer ataupedagang eceran yang berukuran kecil dansederhana, misalnya toko-toko kelontong,pengecer atau pedagang eceran yangberada di pinggir jalan, pedagang eceranyang berada di pasar tradisional, dan lainsebagainya. Kelompok bisnis ritel inimemiliki modal yang sedikit denganfasilitas yang sederhana, lengkap dan modern. Ritel modernadalah sejumlah pedagang eceran ataupengecer berukuran besar, misalnya dengan jumlah gerai yang cukup banyakdan memiliki fasilitas toko yang sangatlengkap dan modern (Soliha, 2008).

Direktoat Jendral Perdagangan Dalam Negeri, DepartemenPerdagangan Republik Indonesia (1997), terdapat sebelas jenisperdagangan ritel atau eceran, terdiri dari pasar tradisional, supermarket (swalayan/rumah belanja), departementstore (toko serba ada), pasar grosir, pasar grosir tradisional, pasar grosir modern,pusat perbelanjaan/pusat perdagangan (mall/plaza/shoppingcenter), toko bebas pajak (duty free shop), pasar percontohan, pertokoan, dan pasar induk.

Pertumbuhan perdagangan ritel di Bali khususnya Kota Denpasar sendiri mengalami peningkatan setiap tahunnya dilihat dari banyaknya bermunculan gerai-gerai ataupun toko-toko yang berkontribusidalam pesatnya industri ritel. Tahun 2018 terdapat 18 daftar nama ritel moderen diKota Denpasar yang di antaranya adalah Carefour, Giant, Matahari, Level 21, Plaza Renon, Ramayana Robinson Diponegoro,Ramayana Robinson Sesetan, Ramayana Robinson Sudirman, Tiara Dewata, Tiara Monang-Maning, Hardy's Mall Sesetan, Hardy's MallPanjer, Hardy's Mall Sanur, Hardy’s Mall Gatsu, Clandy’s, Tiara Grosir, Toserba Daimaru, dan Tiara Gatsu.

Ramayana department storeadalah perusahaan ritel yang menawarkan sejumlah besar barang dengan kategori produk yang berbeda, seperti pakaian pria, wanita, anak-anak, bayi, sepatu dan sendal. Kriteria yang menjadi pertimbangan pihak Ramayana department store adalah pemilihan lokasi yang strategis dekat dengan areal perkantoran, sekolah, kampus, tempat makan danmudah diakses dengan angkutan umum serta konsep one stop shopping yang terdiri daridepartment store, Ramayana Supermarket, tempat makan California Fried Chicken(CFC), Zone 2000 arena bermain keluarga, dan food connection yang memungkinkan untuk berbelanja segala macam kebutuhan dalam satu tempatdan berdampak paada peningkatan volume kunjungan ke Ramayana department storeyang terlihat dari banyaknya masyarakat yang berkunjung setiap harinya.

(Abdolvand et al., 2011) menyatakan bahwa impulse buying merupakan aspek penting dalam perilaku konsumen dan konsep yang vital bagi peritel. Pembelian impulse telah dianggap sebagai fenomena yang khas dan meresap 
dalam gaya hidup seseorang dan terus mengalami peningkatan (Ahad et al.,2015) Impulse buyingterjadi ketika seseorang belum mencari produk tertentu dan belum memiliki niat untuk membeli (Khorrami et al.,2015). Pembelian impulse juga dikarenakan dorongan yang berlebihan untukmembeli tanpa pertimbangan yang hati-hati dari alternatif yang tersedia serta kurangnya niat pembelian sebelumnya (Tom, 2015). Penelitan yang dilakukan oleh Muthiah et al. (2018) memperlihatkan bahwa variabel visual merchandising, display product, dan atmosfer tokosecara bersama-samaatau secara simultan berpengaruh positif dan signifikan terhadap perilaku impulsebuying di Mataharidepartment storedi Kota Makassar. Astuti \& Fillippa (2008) menyebutkan bahwa sekitar 75 persenpembelian di supermarket dilakukan secara takterencana. Choudhary(2014)bahkan menyebutkan kira-kira 80 persen pembelian adalah pembelian tidak terencana.Bayley et al.(1998) diperkirakan 65 persen keputusan pembelian di supermarket dilakukan di dalam toko dengan lebih dari 50 persen merupakan impulse buying.

Adanya pembelian impulse ini memberikan pengaruh positif bagi peritel fashion guna meningkatkn omzet penjualan perusahaan. Pemahaman mengenai perilaku impulse buying dapat memberikan pedoman bagi peritel dalam mengembangkan strategi yang menambah peluang dalam berbelanja. Hal ini menguatkan bahwa impulse buying yang dilakukan oleh konsumen atau pelanggan sangat berkontribusi dalam meningkatkan omset penjualan yang didapat oleh peritel tersebut.

Christina (2010:69) menjelaskan bahwa salah satu penyebab terjadinyapembelian impulsif adalah pengaruh stimulus dari tempat belanja tersebut, danmenurut (Maymand \& Ahmadinejad, 2011) lingkungan stimulasi termasuk dalamrangsangan eksternal dimana rangsangan eksternal pembelian impulse mengacupada rangsangan pemasaran yang dikontrol dan dilakukan oleh pemasarmelalui kegiatan visualmerchandising, penciptaan atmosfer toko dan display pada produknya.Visual merchandising merupakan teknik dalam mempresentasikan tampilan barang dagangan yang menarik eyecatching dan ditujukan pada pelanggan potensial (Jain et al.,2012). Visual merchandising sangat penting untuk menarik perhatian konsumen, terlihat dari 83 persen informasi yang diserap oleh seseorang berasal dari objek yang mereka lihat (Das et al.,2015).Visual merchandising berperan dalam menambahkan informasi untuk barang dagangan, melengkapi barang dagangan tertentu, dan membangun strategi pengiriman pesan melalui gambar yang kemudia mendorong konsumen untuk melakukan pembelian impulse (Kim, 2013).

Faktor penting lainnya yang ikut berkontribusi dalam mempengaruhi impulse buyingadalah atmosfer toko. Bisnis ritel terutama pada ritel modern, suasana toko sangat diperhatikan agar dapat menarik para konsumen dan dapat membuat konsumen nyaman berbelanja di dalamnya(Hussain et al., 2015). Suasana yang nyaman menjadi bahan pertimbangan tersediribagi konsumen sebelum memutuskan untukdatang atau mengunjungi gerai tertentu (Meldarianda, 2010). Teori Store andAtmosphere (Levy dan Weitz, 2007) menyatakan lingkungan toko merupakan suasana yang bisa menstimulasi 5 indra konsumen dan mempengaruhi persepsi dan emosi konsumen terhadap toko. Gillani (2012) 
menjelaskan bahwa dalam bisnis yang kompetitif saat ini, atmosfer toko dianggap sebagai salah satu hal yang penting bagi toko ritel.

Faktor pentinglainnya yang ikut mendongkrak naik impulse buyingadalah display produk atau dikenal dengan penataan produk.Menata produk adalah salah satu aspek penting untuk menarik konsumen agar masuk dan melihat barang pada toko kemudian dapat mendorong keinginan konsumen yang pada saat datang ke toko untuk membeli suatu produk melalui daya tarik penglihatan langsung pada suatu produk. Displayproduk dianggap sebagai alat pemasaran yang kuat dan merukapakan bagian dari Point of Purchase Stimuli (POP Stimuli) untuk memotivasi konsumen dalam membeli produk dengan dorongan impulse(Sarma, 2014). Toko harus menciptakan daya tarik penataan ruang dan penyusunan produk sehingga konsumen atau pelanggan merasa betah dan nyaman dalam berbelanja.

Alasan peneliti melakukan studi ini karena mempertimbangkan adanya perbedaan hasil-hasil penelitian sebelumnya dengan penggunaan variabel yang sama. Hasil penelitianyang dilakukan oleh Thomas et al. (2018), Prasad \& Vetrivel (2016), dan Hadjali et al. (2012), Rathee \& Prakash (2017), Sari \& Suryani, (2017), memperlihatkan bahwa kegiatan merchandising dapat meningkatkan impulse buying, namun penelitian yang dilakukanoleh Soeseno (2011), Muthiah et al. (2018) memperlihatkan bahwa kegiatan merchandising dalam toko tidak berpengaruh signifikan terhadap pembelian impulse.

Hasil penelitian yang dilakukan oleh Yistianiet al. (2012), Pancaningrum(2017),Pemayun \& Ekawati (2016) memperlihatkan bahwaatmosfer toko dapat meningkatkan impulse buyingsecara signifikan, namun penelitian yang dilakukan oleh Hadjali et al. (2012), Muthiah et al. (2018) menunjukan bahwa atmosfer toko tidak berpengaruh signifikan terhadap impulse buying.

Penelitian sebelumnya yang dilakukan oleh Muthiah et al. (2018)menjelaskan bahwa variabel display produk secara parsial berpengaruh signifikan terhadap keputusan pembelian impulse, sedangkan penelitian yang dilakukan oleh Rahmadana (2016)menjelaskan bahwa variabel display produk secara parsial tidak berpengaruh signifikan terhadap keputusan pembelian impulse.Berdasarkan fenomena yang telah dibahas pada latar belakang tersebut, maka peneliti tertarik untuk meneliti mengenai "Pengaruhvisual merchandising,atmosfer toko, dan display produk terhadap impulse buyingpelanggan Ramayana departmentstore di Denpasar".

Tujuan dari penelitian ini adalah untuk menjelaskan pengaruh visual merchandising terhadap impulse buyingpelanggan Ramayana departmentstore di Denpasar. Menjelaskan pengaruh atmosfer toko terhadap impulse buyingpelanggan Ramayana departmentstore di Denpasar. Menjelaskan pengaruh display produk terhadap impulse buyingpelanggan Ramayana departmentstore di Denpasar.

Perilaku konsumen menurut Kotler dan Amstrong (2008: 214) merupakan suatu kegiatan konsumen dalam mencari, membeli, menggunakan, mennilai manfaat hingga membuang produk atau jasa yang telah dipakai dan berharap mampu memenuhi kebutuhan yang diinginkan.Ketika para pemasar memahami perilaku konsumennya, maka mereka akan bisa memprediksi bagaimana 
konsumen akan bereaksi terhadap berbagai isyarat pemasaran dan isyarat lingkungan sehingga berdasarkan hasil prediksi itu mereka bisa mempertajam strategi pemasaran yang sesuai (Suprapti,2010:6).

Theory of Reasoned Action (TRA) atau teori tindakan beralasan mengasumsikan perilaku ditentukan oleh keinginan individu untuk melakukan atau tidak melakukan suatu perilaku tertentu atau sebaliknya yang dalam hal ini berkaitan dengan perilaku pembelian tanpa terencana(Ajzen et al., 2005). Berdasarkan teori tindakan beralasan perilaku pembelian seseorang ditentukan oleh dua faktor, yaitu sikap berperilaku secara individu (individual's attitude toward the behavior)dan norma subjektif (subjectivenorm)

Proses tampilan visual merchandising bahkan seringkali disebut sebagai "silent salesperson" yang menyediakan informasi melalui media visual serta dengan menjual secara sugestif atau saran untuk menambahkan item ke pembelian konsumen (Bhalla and Anuraag, 2010).Visualmerchandising adalah cara pengadangan barang dan iklan oleh gerai toko agar terlihat menarik dan merangsang pembelian oleh konsumen.

Visualmerchandising adalah cara pengadangan barang dan iklan oleh gerai toko agar terlihat menarik dan merangsang pembelian oleh konsumen.Terdapat beberapa indikator yang mendukung pengadaan visual merchandising dalam sebuah toko (Mehta and Chugan, 2013), yaitu: 1. Window display adalah tampilan depan dari sebuah toko yang membantu pelanggan memutuskan apakah akan memasuki toko atau tidak, 2. Mannequin display adalah salah satu alat komunikasi bagi ritel fashion yang digunakan untuk memamerkan atau menjelaskan tren fashion saat ini, 3. Promotional signageadalah salah satu indkator dari visual merchandising yang membantu meningkatkan penjualan dengan memberikan informasi mengenai produk dan menyarankan item atau pembelian khusus, 4. Floormerchandising adalah penataan peralatan-peralatan yang mendukung pelaksanaan bisnis ritel dalam menciptakan ruang gerak bagi konsumen di dalam toko.

Atmosfer toko merupakan suasana terencana yang sesuai dengan pasar sasarannyadan yang dapat menarik konsumen untukmembeli (Kotler, 2016). Atmosfer toko mempengaruhi keadaan emosi pembeli yangmenyebabkan atau mempengaruhi pembelian.Keadaan emosional akan membuat dua perasaanyang dominan yaitu perasaan senang danmembangkitkan keinginan.

Atmosfer toko adalah rancangan dan suatu desain lingkungan melaluikomunikasi visual, pencahayaan, warna, musik dan penciuman untuk merangsang persepsi dan emosi dan pelanggan dan akhirnya untuk mempengaruhi perilaku pembelanjaan merekaRahmadana (2016). Atmosfer toko dapat didefinisikan sebagai rancangan dan suatu desain lingkungan melalui komunikasi visual pada suatu toko melalui pemilihan dan pengaturan fasilitas fisik toko dan aktivitas barang dagangan sehingga menimbulkan kesan yang menarik dan menyenangkan bagi konsumen untuk melakukan pembelian. Atmosfer dapat tercipta dari melalui bebrapa indikator, yaitu:1. Desain gerai, mencakup desain di lingkungan gerai, yaitu desain eksterior, layout, dan ambience. Desain eksterior mencakup wajah gerai, marquee, pintu masuk, dan jalan masuk. Layout atau tata letak berkaitan dengan alokasi ruang untuk penempatan produk yang akan 
dijual. Ambience adalah atmosfer dalam gerai yang menciptakan perasaan tertentu dalam diri pelanggan yang ditimbulkan dari penggunaan unsur unsur interior, pengaturan cahaya, tata suara, sistem pengaturan udara, dan pelayanan. Desain gerai yang tepat akan membantu tercapainya sasaran komunikasi visual. Desain gerai, merupakan strategi penting dalam menciptakan atmosfer (suasana gerai) yang nyaman, sehingga dapat membuat pelanggan merasa betah berada dalam suatu gerai, 2. Perencanaan gerai, mencakup layout (tata letak) dan alokasi ruang. Layout mencakup rencana jalan atau gang dalam gerai dan sirkulasi arus orang. Perencanaan gerai, merupakan tata letak yang baik yang akan memudahkan konsumen untuk berjalan dan menemukan produk yang diinginkan dalam gerai, 3 . Komunikasi visual, komunikasi visualmerupakan komunikasi perusahaan ritel dengan konsumen melalui wujud fisik berupa identitas pengusaha ritel, grafis, dan instorecommunication. Identitas pengusaha ritel dapat berupa wajah gerai dan marquee. Kedua hal inilah yang pertama kali dilihat oleh calon pembeli ketika berniat berbelanja, sedangkan grafis merupakan pendukung dari komunikasi dalam gerai yang melibatkan tata suara, tekstur, entertainment, promosi, dan personal. Komunikasi visual merupakan hal penting yang harus diperhatikan pemilik ritel. Komunikasi visual terdiri dari logo, iklan, grafis dan tulisan-tulisan yang dapat dilihat dan dirasakan bermanfaat bagi konsumen.

Alma (2014:189) display yaitu keinginan membeli sesuatu, yang tidak didorong oleh seseorang, tetapi didorong oleh daya tarik, atau oleh penglihatan ataupun oleh perasaan lainnya. Menata produk adalah salah satu aspek penting untuk menarik konsumen agar masuk dan melihat barang pada toko kemudian dapat mendorong keinginan untuk membeli suatu produk.Rahmadana (2016)menyatakan display produk adalahusaha yang dilakukan untuk menata barang yang mengarah pembeli agar tertarik untukmelihat dan memutuskan untuk membelinya.

Rahmadana (2016) menjelaskan pada dasarnya penataan barang (display) mempunyai beberapa macam indikator, yaitu: 1. Window display merupakan suatu pemajangan barang, gambar, kartu harga dan simbol dibagian depan toko yang disebut etalase. Tujuan dari window display yaitu untuk menarik perhatian konsumen yang lewat, memancing perhatian terhadap barang-barang istimewa yang dijual di toko, menimbulkan impulse buying (dorongan seketika), menimbulkan daya tarik terhadap keseluruhan suasana toko menyatakan kualitas barang yang baik atau harga yang murah sebagai ciri khas toko tersebut, 2 . Interior display adalah pemajangan barang, gambar, kartu harga, poster di dalam toko misalnya di lantai, rak, dan meja-meja. Interior display mempunyai beberapa macam yaitu merchandise display berkenaan dengan teknik penyajian barangbarang dalam gerai untuk menciptakan situasi atau suasana tertentu. Komposisi rak dipajang dan disusun tegak (verticaldisplay). Store sign yaitupenyajian yang memberikan informasi tentang lokasi barang di dalam toko membimbing calon pembeli ke arah barang dagangan yang dibutuhkan (tanda arah petunjuk produk). Dealer display merupakan simbol, petunjuk-petunjuk mengenai penggunaan barang yang dibuat oleh produsen, 3. Eksterior display adalah pemajangan barang, gambar, poster, dan simbol di luar toko. Pemajangan sistem ini banyak digunakan untuk promosi barang, pengenalan produk baru, penjualan istimewa, 
cuci gudanng, dan diskon. Fungsi dari eksterior display ini adalah memperkenalkan produk dengan cepat dan ekonomis, membantu mengkoordinir advertising dan merchandising, membantu para produsen meyalurkan barangbarangnya dengan cepat dan ekonomis.

Kacen \& Lee (2012) menyimpulkanImpulse buying adalah pembelian yang tidak direncanakan, hasil dari rangsangan stimulus, dan diputuskan saat itu juga ditempat. Setelah melakukan pembelian, konsumen merasakan reaksi yang cognitive dan emosional." Pendapat tersebut menunjukkan bahwa impulse buying timbul karena adanya rangsangan dan dibeli seketika meskipun tidak ada perencanaan pembelian sebelumnya.Impulse buying dapat disimpulkan sebagai pembelian yang dilakukan oleh konsumen di dalam toko yang tidak direncanakan sebelumnya.

Indikator untuk mengukur impulse buying ini adalah sebagai berikut: Tidak ada perencanaan untuk membeli produk, dimana konsumen membeli begitu saja ketika melihat barang tersebut, tidak memerlukan pertimbangan yang panjang untuk melakukan pembelian, pembelian terjadi karena adanya rangsangan dari produk, dari labeling, warna, dan lainnya.

Perilaku pembelian ini seringdidasarkan pada adanya stimulus langsung dan sering disertai dengan perasaan kegembiraan, kesenangan atau dorongan kuat untuk membeli. Ada dua faktor yang mempengaruhi impulse buying yaitu faktor internal dan faktor eksternal. Pembelian impulsif biasanya timbul ketika konsumen berada di dalam toko dan dirangsang oleh stimuli eksternal (berupa produk yang dilihatnya).

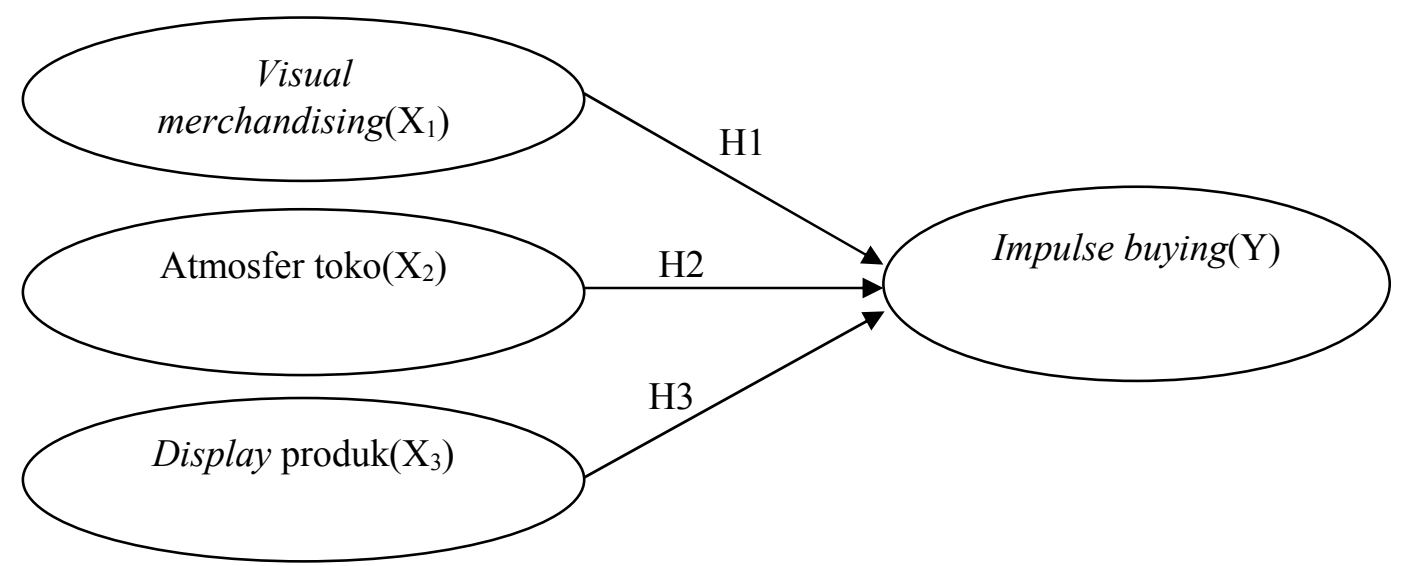

Gambar 1. Kerangka Konseptual

Berdasarkan penelitianyang dilakukan oleh Thomas et al.(2018), Prasad \& Vetrivel (2016), Hadjali et al. (2012), Rathee \& Prakash (2017), Sari \& Suryani, (2017),memperlihatkan bahwa kegiatan visualmerchandising yang dilakukanperitel dapat meningkatkan impulse buyingpada perusahaan ritel, namun penelitian yang dilakukanoleh Soeseno (2011), dan Muthiah et al. (2018)memperlihatkan bahwa kegiatan merchandising yangtergabung dalam 
variabel stimulus dalam toko tidak berpengaruh signifikanterhadap pembelian impulsedi Matahari department store.

$\mathrm{H}_{1}$ :Visual merchandisingberpengaruh positif dan signifikan terhadap impulse buying.

Berdasarkan Hasil penelitian yang dilakukan oleh Yistianiet al. (2012), Pancaningrum(2017),Pemayun \& Ekawati (2016) memperlihatkan bahwa atmosfer toko dapat meningkatkan impulse buyingsecara signifikan pada Hardy's Mall Gatsu Denpasar, namun penelitian yang dilakukan oleh Hadjali et al.(2012) dan Muthiah et al. (2018) menunjukan bahwa atmosfer toko tidak berpengaruh signifikan terhadap impulse buyingdi Matahari department storedi Makassar.

$\mathrm{H}_{2}$ :Atmosfer toko berpengaruh positif dan signifikan terhadap impulse buying.

Penelitian sebelumnya yang dilakukan oleh Muthiah et al. (2018) menjelaskan bahwa variabel display produk secara parsial berpengaruh signifikan terhadap keputusan pembelianimpulse di Matahari department store di Makassar, sedangkan penelitian yang dilakukan oleh Rahmadana (2016)menjelaskan bahwa variabel display produk secara parsial tidak berpengaruh signifikan terhadap keputusan pembelian impulse di Minimarket Eramart cabang Lembuswana Samarinda.

$\mathrm{H}_{3}$ :Display produk berpengaruh positif dan signifikan terhadap impulse buying.

\section{METODE PENELITIAN}

Jenis penelitian ini menggunakan pendekatan kuantitatif yang berbentuk asosiatif. Penelitian ini di lakukan di Ramayana department store, Jl. Diponegoro No. 103 Denpasar, Bali. Objek dalam penelitian ini adalah pengaruh visual merchandising, atmosfertoko, dan display produk terhadap impulse buyingpelanggan Ramayana department storedi Denpasar. Variabel bebas dalam penelitian ini adalah visual merchandising $\left(\mathrm{X}_{1}\right)$, atmosfertoko $\left(\mathrm{X}_{2}\right)$, dan display produk $\left(\mathrm{X}_{3}\right)$.Variabel terikat adalah variabel yang dipengaruhi atau yang menjadi akibat karena adanya variabel bebas. Dalam penelitian ini yang menjadi variabel terikat adalah impulse buying (Y).Populasi dalam penelitian ini adalah seluruh masyarakat yang sudah pernah membeli produk di Ramayana department store, Jl. Diponegoro No. 103 Denpasar, Bali dengan sampel sebanyak 100 responden. Teknik pengambilan sampel yang akan digunakan dalam penelitian ini adalah nonprobability sampling engan purposivesampling.

Data dalam penelitian ini dikumpulkan melalui instrument penelitian berupa kuesioner. Metode pengumpulan data berupa penyebaran kuesionermenggunakan skala likert. Rumus interval kelas adalah sebagai berikut:

$$
\text { Interval kelas }=\frac{\text { Nilai tertinggi }- \text { nilai terendah }}{\text { Jumlah kelas }}
$$

Penelitian ini menggunakan jenis data yang dikelompokkan menurut sifatnya yaitu, data kualitatif dan kuantitatif.Sumber data yang digunakan pada penelitian ini adalah sumber primer dan sekunder.Teknik analisis data yang digunakan adalah analisis regresi linier berganda. 
Analisis ini digunakan untuk mengetahui besarnya pengaruh secara simultan visualmerchandising, atmosfer toko, display produk dan impulsebuying.Regresi linier berganda dinyatakan dalam bentuk persamaan garis regresi linier berganda sebagai berikut (Sugiyono, 2013:277):

$$
\begin{aligned}
& \mathrm{Y}=\mathrm{a}+\mathrm{b}_{1} \mathrm{X}_{1}+\mathrm{b}_{2} \mathrm{X}_{2}+\mathrm{b}_{3} \mathrm{X}_{3} \\
& \text { Dimana } \\
& \mathrm{Y}=\text { Impulse buying } \\
& \mathrm{a}=\text { Nilai konstanta } \\
& \mathrm{X}_{1}=\text { Visual merchandising } \\
& \mathrm{X}_{2}=\text { Atmosfer toko } \\
& \mathrm{X}_{3}=\text { Display produk } \\
& \mathrm{b}_{1}=\text { Koefisien regresi visual merchandising }\left(\mathrm{X}_{1}\right) \\
& \mathrm{b}_{2}=\text { Koefisien regresi atmosfer toko }\left(\mathrm{X}_{2}\right) \\
& \mathrm{b}_{3}=\text { Koefisien regresi display produk }\left(\mathrm{X}_{3}\right)
\end{aligned}
$$

Visual merchandising didefinisikan sebagai teknik mempresentasikan barang dagangan yang dilakukan oleh Ramayana department storeagar tampil lebih menarik. Indikator dari visual merchandising adalah sebagai berikut (Mehta and Chugan, 2013) : 1. Window display, tampilan depan toko yang digunakan konsumen untuk mengobservasi toko seperti apakah jenis barang dan kategori yang dijualpada Ramayana department storedi Denpasar sebagai bahan pertimbangan kunjungan, 2. Mannequin display, pengaturan produk yang sedang trend pada mannequin guna memberi tampilan produk lebih menarik dan memotivasi konsumen untuk membeli padaRamayana department storedi Denpasar, 3. Promotional signage, segala bentuk petunjuk ataupun informasi mengenai produk ataupun program khusus yang terdapat pada Ramayana department storedi Denpasar, 4. Floor merchandising, pengaturan barang-barang interior dan layout toko secara terampil guna menghasilkan ruang gerak yang nyaman pada Ramayana department storedi Denpasar.

Atmosfer toko merupakan suasana terencana yang sesuai dengan pasar sasarannyadan yang dapat menarik konsumen untukmembeli (Kotler, 2016). Atmosfer toko mempengaruhi keadaan emosi pembeli yangmenyebabkan atau mempengaruhi pembelian.Ma'ruf (2006) memaparkan bahwa atmosfer dapat tercipta dari melalui bebrapa indikator, yaittu : 1. Desain geraipada Ramayana department storedi Denpasar yang nyaman, sehingga dapat membuat pelanggan merasa nyaman berada dalam suatu gerai., 2. Perencanaan geraipada Ramayana department storedi Denpasar mencakup layout (tata letak) dan alokasi ruang guna mengaturpenataan barang, 3. Komunikasi visualpada Ramayana department storedi Denpasar melalui wujud fisik berupa grafis, dan instorecommunication, terdiri dari logo, iklan, grafis dan tulisan-tulisan yang dapat dilihat dan dirasakan bermanfaat bagi konsumen.

Buchari Alma (2014:189) menyatakan display yaitu keinginan membeli sesuatu, yang tidak didorong oleh seseorang, tetapi didorong oleh daya tarik, atau oleh penglihatan ataupun oleh perasaan lainnya. Rahmadana (2016) menjelaskan pada dasarnya penataan barang (displayproduk) mempunyai beberapa macam indikator, yaitu: 1. Window displaypada Ramayana department storedi Denpasar 
meliputi pemajangan barang, gambar, kartu harga dan simbol dibagian depan toko yang disebut etalase, 2. Interior display pada Ramayana department storedi Denpasar meliputi pemajangan barang, gambar, kartu harga, poster di dalam toko misalnya di lantai, rak, dan meja-meja, 3. Eksterior display pada Ramayana department storedi Denpasar meliputi pemajangan barang, gambar, poster, dan simbol di luar toko. Pemajangan sistem ini banyak digunakan untuk promosi barang, pengenalan produk baru, penjualan istimewa, dan diskon.

Pontoh dkk (2017) Pembelian yang tidak direncanakan merupakan perilaku pembelian yang dilakukan didalam toko, dimana pembelian berbeda dari apa yang telah direncanakan oleh konsumen pada saat berada didalam toko. Perilaku pembelian ini seringdidasarkan pada adanya stimulus langsung dan sering disertai dengan perasaan kegembiraan, kesenangan atau dorongan kuat untuk membeli. Kacen and Julie Anne Lee (2002) menyatakan bahwa indikator untuk mengukur impulse buying ini adalah sebagai berikut: 1. Tidak ada perencanaan untuk membeli produkpada Ramayana department storedi Denpasar, 2. Tidak memerlukan pertimbangan yang panjang untuk melakukan pembelianproduk pada Ramayana department storedi Denpasar, 3. Pembelian pada Ramayana department storedi Denpasar terjadi karena adanya rangsangan dari produk, labeling, warna.

Tabel 1.

Operasional Variabel Penelitian

\begin{tabular}{|c|c|c|c|}
\hline No. & Variabel & Indikator & Sumber \\
\hline 1. & $\begin{array}{l}\text { Visualmerchandising } \\
\qquad\left(\mathrm{X}_{1}\right)\end{array}$ & 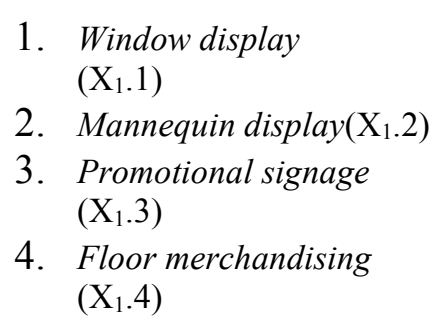 & $\begin{array}{c}\text { (Mehta and } \\
\text { Chugan, 2013) }\end{array}$ \\
\hline 2. & $\begin{array}{c}\text { Atmosfer Toko } \\
\left(\mathrm{X}_{2}\right)\end{array}$ & $\begin{array}{ll}\text { 1. } & \text { Desain gerai } \\
& \left(\mathrm{X}_{2} .1\right) \\
\text { 2. } & \text { Perencanaan gerai } \\
& \left(\mathrm{X}_{2} .2\right) \\
\text { 3. } & \text { Komunikasi visual } \\
\left(\mathrm{X}_{3} .3\right)\end{array}$ & $\begin{array}{l}\text { Ma'ruf } \\
(2006)\end{array}$ \\
\hline 3. & $\begin{array}{l}\text { Display Produk } \\
\left(\mathrm{X}_{3}\right)\end{array}$ & $\begin{array}{ll}\text { 1. } & \text { Window display } \\
& \left(\mathrm{X}_{3} .1\right) \\
\text { 2. } & \text { Interior display }\left(\mathrm{X}_{3} .2\right) \\
\text { 3. } & \text { Exterior display } \\
& \left(\mathrm{X}_{3} .3\right)\end{array}$ & Kammadana (2010) \\
\hline
\end{tabular}

bersambung... 
lanjutan Tabel 1.

\begin{tabular}{|c|c|c|c|}
\hline No. & Variabel & Indikator & Sumber \\
\hline \multirow[t]{3}{*}{4.} & $\begin{array}{c}\text { Impulse Buying } \\
\text { (Y) }\end{array}$ & $\begin{array}{l}\text { 1. Pembelian Tidak } \\
\text { Terencana } \\
\text { (Y1) }\end{array}$ & $\begin{array}{l}\text { Kacen and Julie } \\
\text { Anne Lee (2002) }\end{array}$ \\
\hline & & $\begin{array}{l}\text { 2. Pembelian Tanpa Pikir } \\
\text { Panjang } \\
\text { (Y2) }\end{array}$ & \\
\hline & & $\begin{array}{l}\text { 3. Pembelian Karena } \\
\text { Rangsangan Produk } \\
\text { (Y3) }\end{array}$ & \\
\hline
\end{tabular}

\section{HASIL DAN PEMBAHASAN}

PT Ramayana Lestari Sentosa, Tbk didirikan di Indonesia pada tangga 14 Desember 1983. Bisnis utama Ramayana adalah penjualan pakaian dan aksesoris pria, wanita dan anak-anak, termasuk aksesoris dan barang-barang fesyen lainnya, sepatu, mainan anak-anak, barang-barang kebutuhan rumah tangga melaui gerai serba ada (department store). Selain itu Ramayana juga menjalin kerjasama dengan SAR International yaitu sebuah jaringan retail dan franchise multinasional Belanda yang memiliki sekitar 12.500 toko di 35 negara di seluruh dunia dengan menggunakan nama SPAR Supermarket.

Saat ini (08/11/2018), jumlah gerai yang dioperasikan oleh PT Ramayana Lestari Sentosa, Tbk terdiri dari 116 gerai dengan nama Ramayana (106 gerai), Robinson (7 gerai) dan Cahaya (3 gerai), yang tersebar di wilayah Indonesia. Ramayana department store melengkapi kebutuhan masyarakat kelas pekerja Indonesia yang tinggal di kawasan perkotaan, terutama pulau Bali dan di seluruh Indonesia dengan menjual produk-produk paling modern dan bergaya dengan harga yang terjangkau. Ramayana sangat memperhatikan penataan visualmerchandising, atmosfer toko dan display produknya sebagai upaya penambahanmutu, layanan, nilai dan mengaitkan kesuksesan dan ekspansi yang terus diraihnya agar selalu tanggap dengan kondisi ekonomi, sosial dan pasar.

Responden dalam penelitian ini yaitu sejumlah 100 orang sesuai dengan ukuran sampel yang digunakan. Responden penelitian akan digambarkan dengan menyajikan karakteristik responden yang didasarkan pada variabel demografi yang terdiri dari jenis kelamin beserta pendidikan terakhir.

Berdasarkan data karakteristik responden yang ada pada Tabel 2. untuk klasifikasi jenis kelamin pada penelitian ini menunjukkan hasil yang di dominasi lebih banyak oleh perempuan sebesar 65 persen dibandingkan dengan persentase responden yang berjenis kelamin laki - laki sebesar 35 persen. Kondisi ini menunjukkan bahwa secara umum responden pada penelitian ini merupakan perempuan. 
Tabel 2.

Karakteristik Responden

\begin{tabular}{|c|c|c|c|c|}
\hline No & Kriteria & Klasifikasi & $\begin{array}{l}\text { Jumlah } \\
\text { (Orang) }\end{array}$ & $\begin{array}{c}\text { Persentase } \\
(\%)\end{array}$ \\
\hline \multirow[t]{3}{*}{1} & Jenis kelamin & Laki-laki & 35 & 35 \\
\hline & & Perempuan & 65 & 65 \\
\hline & Jumlah & & 100 & 100 \\
\hline \multirow[t]{5}{*}{2} & Pendidikan Terakhir & SMA/SMK Sederajat & 52 & 52 \\
\hline & & Diploma & 3 & 3 \\
\hline & & S1 & 41 & 41 \\
\hline & & $\mathrm{S} 2$ & 4 & 4 \\
\hline & Jumlah & & 100 & 100 \\
\hline \multirow[t]{5}{*}{3} & Pekerjaan/ Status & Pelajar atau Mahasiswa/i & 31 & 31 \\
\hline & & ASN/TNI Polri & 7 & 7 \\
\hline & & Pegawai Swasta & 37 & 37 \\
\hline & & Wiraswasta & 25 & 25 \\
\hline & Jumlah & & 100 & 100 \\
\hline \multirow[t]{6}{*}{4} & Penghasilan/Uang & $<\operatorname{Rp} 1.000 .000$ & 10 & 32 \\
\hline & & $\operatorname{Rp} 1.000 .000-<\operatorname{Rp} 3.000 .000$ & 46 & 46 \\
\hline & & $\operatorname{Rp} 3.000 .000-<\operatorname{Rp} 5.000 .000$ & 25 & 25 \\
\hline & & $\operatorname{Rp} 5.000 .000-<\operatorname{Rp} 7.000 .000$ & 12 & 12 \\
\hline & & $\geq \operatorname{Rp} 7.000 .000$ & 7 & 7 \\
\hline & Jumlah & & 100 & 100 \\
\hline
\end{tabular}

Sumber: Data diolah, 2018

Begitu pula dilihat dari klasifikasi pendidikan terakhir responden pada jenjang pendidikan terakhir pada bangku SMA/SMK sederajat memperoleh persentase terbesar yaitu sebanyak 52 pesen, disusul dengan strata 1 sebanyak 41 persen, sedangkan jenjang pendidikan terakhir pada tingkat strata 2 memiliki persentase sebesar 4 persen. Responden yang berpendidikan terakhir diploma hanya sebesar 3 persen. Kondisi ini menunjukkan bahwa secara umum responden pada penelitian ini memiliki tingkat pendidikan terakhir yang ditempuh yaitu SMA/SMK sederajat. Data tersebut menunjukkan bahwa responden dengan klasifikasi pendidikan terakhir SMA/SMK sederajat pada jenjang ini merupakan konsumen produktif Ramayana department store yang sering mengunjungi gerai Ramayana.

Berdasarkan hasil penelitian pada Tabel 2.menunjukkan sebagian besar responden dengan pekerjaan sebagai pegawai swasta sebanyak 37 persen. Sedangkan responden dengan pekerjaan pelajar atau mahasiswa/i sebanyak 31 persen, kemudian wiraswatsa 25 persen dan yang paling sedikit adalah responden dengan pekerjaan Aparatur Sipil Negara (ASN) atau TNI Polri sebanyak 7 persen. Kondisi ini menunjukkan bahwa secara umum responden pada penelitian ini memiliki pekerjaan sebagian besar sebagai pegawai swasta. Untuk tingkat penghasilan/uang saku perbulan sendiri lebih didominasi oleh responden dengan tingkat penghasilan $\mathrm{Rp} 1.000 .000-<\mathrm{Rp} 3.000 .000$ sebanyak 46 persen yang termasuk tingkat penghasilan/uang saku perbulan menengah kebawah. 
Tabel 3.

Hasil Uji Validitas Instrumen

\begin{tabular}{ccccc}
\hline No & Variabel & Item Pernyataan & Korelasi Item Total & Keterangan \\
\hline 1 & Visual Merchandising & $\mathrm{X}_{1.1}$ & 0.889 & Valid \\
& $\left(\mathrm{X}_{1}\right)$ & $\mathrm{X}_{1.2}$ & 0.780 & Valid \\
& & $\mathrm{X}_{1.3}$ & 0.813 & Valid \\
& & $\mathrm{X}_{1.4}$ & 0.838 & Valid \\
2 & Atmosfer Toko $\left(\mathrm{X}_{2}\right)$ & $\mathrm{X}_{2.1}$ & 0.903 & Valid \\
& & $\mathrm{X}_{2.2}$ & 0.860 & Valid \\
& & $\mathrm{X}_{2.3}$ & 0.855 & Valid \\
2 & DisplayProduk $\left(\mathrm{X}_{3}\right)$ & $\mathrm{X}_{3.1}$ & 0.834 & Valid \\
& & $\mathrm{X}_{3.2}$ & 0.840 & Valid \\
& & $\mathrm{X}_{3.3}$ & 0.891 & Valid \\
3 & Impulse Buying $(\mathrm{Y})$ & $\mathrm{Y}_{1.1}$ & 0.937 & Valid \\
& & $\mathrm{Y}_{1.2}$ & 0.911 & Valid \\
& & $\mathrm{Y}_{1.3}$ & 0.909 & Valid \\
\hline
\end{tabular}

Sumber: Data diolah, 2018

Hasil uji reliabilitas Tabel 4. menunjukkan bahwa keempat instrument penelitian yaitu variabel visual merchandising, atmosfer toko, display produkdan impulse buying pelanggan Ramayana department storedi Denpasar memiliki koefisien cronbach's alpha> 0,60 sehingga pernyataan pada kuesioner tersebut reliabel.

Hasil uji reliabilitas instrument penelitian untuk menetapkan apakah instrument kuesioner dapat digunakan lebih dari satu kali, dengan responden yang sama disajikan Tabel 4.3 menunjukkan bahwa keempat instrument penelitian yaitu variabel visual merchandising, atmosfer toko, display produkdan impulse buying pelanggan Ramayana department storedi Denpasar memiliki koefisien cronbach's alpha> 0,60 sehingga pernyataan pada kuesioner tersebut reliabel.

Tabel 4.

Hasil Uji Reliabilitas Instrumen

\begin{tabular}{cccc}
\hline No & Variabel & Cronbach's Alpha & Keterangan \\
\hline 1 & Visual Merchandising $\left(\mathrm{X}_{1}\right)$ & 0.843 & Reliabel \\
2 & Atmosfer Toko $\left(\mathrm{X}_{2}\right)$ & 0.839 & Reliabel \\
3 & Display Produk $\left(\mathrm{X}_{3}\right)$ & 0.815 & Reliabel \\
4 & Impulse Buying $(\mathrm{Y})$ & 0.903 & Reliabel \\
\hline
\end{tabular}

Sumber: Data diolah, 2018

Variabel visual merchandising merupakan variabel bebas yang diukur dengan empat pernyataan. Secara rinci hasil penelitian mengenai pendapat responden terhadap variabel visual merchandising disajikan pada Tabel 5.Tabel 5. menunjukkan bahwa 5 pernyataan mengenai visual merchandisingmemperoleh nilai rata-rata sebesar 4,07 yang berarti secara umum responden setuju dengan pernyataan - pernyataan yang merupakan indikator dari visual merchandising. Dengan demikian dapat dikatakan bahwa visual merchandising pada produk Ramayana department store yang dirasakan responden dikategorikan baik.

Data yang dikumpulkan melalui kuesioner yang berisikan pernyataan pernyataan yang menggambarkan penilaian responden mengenai variabel variabel yang ada dalam penelitian dimana jawaban responden digolongkan ke dalam beberapa skala pengukuran dengan kriteria yang mengacu pada Suharso 
(2010:21). Penilaian variabel - variabel penelitian secara menyeluruh akan dilihat dari rata - rata skor dengan kriteria sesuai dengan metode pengumpulan data. Berdasarkan hasil penelitian yang dilakukan di lapangan dapat diketahui tanggapan responden melalui masing - masing indikator dari setiap variabel.

Data Tabel 5. menunjukkan bahwa nilai rata - rata tertinggi jawaban responden melalui empat pernyataan ditunjukkan melalui pernyataan "Produk pada Ramayana department store memberikan trendfashion masa kini" dengan nilai rata - rata sebesar 4,17 yang menunjukkan bahwa responden merasa produk pada Ramayana department store memberikan trend fashion masa kinidibandingkan produk lain yang diketahui responden. Kemudian nilai rata rata sebesar 4,14 menunjukkan bahwa responden merasa informasi yang jelas dan tata letak produk (product shelving) menarik pada Ramayana department store.

Rata - ratasebesar 4,04 menunjukkan bahwa responden merasa ketersediaan jenis produk yang lengkap dan cocok pada Ramayana department store. Nilai rata - rata jawaban terendah sebesar 3,92 ditunjukkan melalui pernyataan "Ruang gerak (space) di Ramayana department store memadai sehingga timbul rasa nyaman saat berbelanja", hal ini berarti bahwa pelanggan Ramayana department store merasa cukup nyaman terhadap ruang gerak yang memadai ketika berbelanja.

Tabel 5.

Deskripsi Jawaban Responden

Mengenai Penilaian Terhadap Variabel Visual Merchandising

\begin{tabular}{|c|c|c|c|c|c|c|c|c|}
\hline \multirow[t]{2}{*}{ No } & \multirow[t]{2}{*}{ Pernyataan } & \multicolumn{5}{|c|}{ Proporsi Jawaban Responden } & \multirow{2}{*}{$\begin{array}{c}\text { Rata } \\
- \\
\text { Rata }\end{array}$} & \multirow{2}{*}{$\begin{array}{c}\text { Kriter } \\
\text { ia }\end{array}$} \\
\hline & & STS & TS & $\mathrm{CS}$ & $\mathrm{S}$ & SS & & \\
\hline 1 & $\begin{array}{l}\text { Ketersediaan jenis produk yang } \\
\text { lengkap dan cocok pada Ramayana } \\
\text { department store }\end{array}$ & - & 2 & 20 & 50 & 28 & 4,04 & Baik \\
\hline 2 & $\begin{array}{l}\text { Produk pada Ramayana department } \\
\text { store memberikan trend fashion masa } \\
\text { kini }\end{array}$ & - & 1 & 15 & 50 & 34 & 4,17 & Baik \\
\hline 3 & $\begin{array}{l}\text { Informasi yang jelas dan tata letak } \\
\text { produk (product shelving) menarik } \\
\text { pada Ramayana department store }\end{array}$ & - & 1 & 15 & 53 & 31 & 4,14 & Baik \\
\hline 4 & $\begin{array}{l}\text { Ruang gerak (space) di Ramayana } \\
\text { department store memadai sehinga } \\
\text { timbul rasa nyaman saat berbelanja }\end{array}$ & - & 1 & 29 & 47 & 23 & 3,92 & Baik \\
\hline
\end{tabular}

Total

4,07 Baik

Sumber: Data diolah, 2018

Tabel 6. menunjukkan bahwa 3 pernyataan mengenai atmosfer toko memperoleh nilai rata-rata sebesar 4,04 yang berarti secara umum responden setuju dengan pernyataan - pernyataan yang merupakan indikator dari atmosfer toko. Atmosfer toko yang dirasakan responden pada gerai Ramayana department store dikategorikan baik mampu memberi kenyamanan saat berada di dalam toko. 
Tabel 6.

Deskripsi Jawaban Responden Mengenai Penilaian Terhadap Variabel Atmosfer Toko

\begin{tabular}{|c|c|c|c|c|c|c|c|c|}
\hline \multirow[t]{2}{*}{ No } & \multirow[t]{2}{*}{ Pernyataan } & \multicolumn{5}{|c|}{ Proporsi Jawaban Responden } & \multirow{2}{*}{$\begin{array}{c}\text { Rata } \\
- \\
\text { Rata }\end{array}$} & \multirow{2}{*}{$\begin{array}{c}\text { Kriter } \\
\text { ia }\end{array}$} \\
\hline & & STS & $\mathrm{TS}$ & $\mathrm{CS}$ & $\mathrm{S}$ & SS & & \\
\hline 1 & $\begin{array}{l}\text { Pencahayaan dan alunan musik di } \\
\text { dalam gerai Ramayana department } \\
\text { store memberi rasanyaman saat } \\
\text { berbelanja }\end{array}$ & - & 4 & 21 & 46 & 29 & 4,00 & Baik \\
\hline 2 & $\begin{array}{l}\text { Tata letak barang di Ramayana } \\
\text { department store memudahkan untuk } \\
\text { berbelanja dan menemukan barang } \\
\text { yang diinginkan }\end{array}$ & - & 4 & 21 & 46 & 29 & 4,00 & Baik \\
\hline 3 & $\begin{array}{l}\text { Penataan barang dan tulisan diskon } \\
\text { yang jelas merangsang untuk } \\
\text { berbelanja di Ramayana department } \\
\text { store }\end{array}$ & - & - & 16 & 55 & 29 & 4,13 & Baik \\
\hline & Total & & & & & & 4,04 & Baik \\
\hline
\end{tabular}

Sumber:Data diolah, 2018

Data pada Tabel 6. menunjukkan bahwa nilai rata - rata tertinggi jawaban responden melalui lima pernyataan ditunjukkan melalui pernyataan "Penataan barang dan tulisan diskon yang jelas merangsang untuk berbelanja di Ramayana department store" dengan nilai rata - rata sebesar 4,13. Hal ini berarti responden merasa setuju dengan penataan barang dan tulisan diskon yang jelas merangsang mereka untuk berbelanja di Ramayana department store.

Tabel 7.

Deskripsi Jawaban Responden

Mengenai Penilaian Terhadap Variabel Display Produk

\begin{tabular}{|c|c|c|c|c|c|c|c|c|}
\hline \multirow[t]{2}{*}{ No } & \multirow[t]{2}{*}{ Pernyataan } & \multicolumn{5}{|c|}{ Proporsi Jawaban Responden } & \multirow{2}{*}{$\begin{array}{c}\text { Rata } \\
- \\
\text { Rata }\end{array}$} & \multirow[t]{2}{*}{ Kriteria } \\
\hline & & STS & TS & $\mathrm{CS}$ & $\mathrm{S}$ & SS & & \\
\hline 1 & $\begin{array}{l}\text { Pemajangan barang, gambar, kartu } \\
\text { harga dan simbol dibagian depan } \\
\text { gerai Ramayana department store } \\
\text { menimbukan keinginan berbelanja } \\
\text { lebih }\end{array}$ & - & 0 & 24 & 49 & 27 & 4,03 & Baik \\
\hline 2 & $\begin{array}{l}\text { Pemajangan barang di dalam gerai } \\
\text { Ramayana department store seperti } \\
\text { di lantai, rak, dan meja-meja tertata } \\
\text { rapi memberi kenyamanan dalam } \\
\text { berbelanja }\end{array}$ & - & 1 & 9 & 52 & 38 & 4,27 & $\begin{array}{l}\text { Sangat } \\
\text { Baik }\end{array}$ \\
\hline \multirow[t]{2}{*}{3} & $\begin{array}{l}\text { Pemajangan barang, gambar, poster, } \\
\text { dan simbol di luar dalam gerai } \\
\text { Ramayana department store seperti } \\
\text { pengenalan produk baru, penjualan } \\
\text { istimewa, cuci gudanng, dan diskon } \\
\text { menarik keinginan untuk memasuki } \\
\text { toko }\end{array}$ & - & 0 & 23 & 44 & 33 & 4,10 & Baik \\
\hline & Total & & & & & & 4,13 & Baik \\
\hline
\end{tabular}

Sumber: Data diolah, 2018 
Tabel 7. menunjukkan bahwa 3 pernyataan mengenai display produk memperoleh nilai rata-rata sebesar 4,13 yang berarti secara umum responden setuju dengan pernyataan - pernyataan yang merupakan indikator dari display produk. Dengan demikian dapat dikatakan bahwa display produkyang dirasakan responden terhadap produk pada Ramayana department store dikategorikan baik.

Data yang ada pada Tabel 7. menunjukkan bahwa nilai rata - rata tertinggi jawaban responden melalui tiga pernyataan ditunjukkan melalui pernyataan "Pemajangan barang di dalam gerai Ramayana department storeseperti di lantai, rak, dan meja-meja tertata rapi memberi kenyamanan dalam berbeanjadengan nilai rata - rata sebesar 4,27. Hal ini berarti responden merasa sangat puas dengan pemajangan barang di dalam gerai Ramayana department store seperti di lantai, rak, dan meja-meja yang menambah kenyamanan dalam berbelanja.

Nilai rata - rata sebesar 4,10 menunjukkan bahwa responden setuju dengan pernyataan "Pemajangan barang, gambar, poster, dan simbol di luar dalam gerai Ramayana department store seperti pengenalan produk baru, penjualan istimewa, cuci gudanng, dan diskonmenarik keinginan untuk memasuki toko". Nilai rata rata terendah jawaban responden ditunjukkan pada pernyataan "Pemajangan barang, gambar, kartu harga dan simbol dibagian depan gerai Ramayana department store menimbuklan keinginan berbelanja lebih" dengan nilai sebesar 4,03 persen.

Tabel 8.

Deskripsi Jawaban Responden

Mengenai Penilaian Terhadap Variabel Impulse Buying

\begin{tabular}{|c|c|c|c|c|c|c|c|c|}
\hline \multirow[t]{2}{*}{ No } & \multirow[t]{2}{*}{ Pernyataan } & \multicolumn{5}{|c|}{ Proporsi Jawaban Responden } & \multirow{2}{*}{$\begin{array}{l}\text { Rata - } \\
\text { Rata }\end{array}$} & \multirow[t]{2}{*}{ Kriteria } \\
\hline & & STS & TS & CS & $\mathbf{S}$ & SS & & \\
\hline 1 & $\begin{array}{l}\text { Proporsi pembelian yang tidak } \\
\text { direncanakan ke Ramayana } \\
\text { department storelebih besar atau } \\
\text { sama denganpembelian yang } \\
\text { direncanakan }\end{array}$ & - & 4 & 31 & 5 & 10 & 3,71 & Baik \\
\hline 2 & $\begin{array}{l}\text { Pada saat melihat produk yang } \\
\text { cocok di Ramayana department } \\
\text { store, tanpa } \\
\text { panjangakanmembeli }\end{array}$ & - & 3 & 15 & 52 & 30 & 4,09 & Baik \\
\hline 3 & $\begin{array}{l}\text { Pada saat melihat barang yang } \\
\text { sungguh-sungguh menarik di } \\
\text { Ramayana department store, } \\
\text { maka akan membelinya seketika, } \\
\text { sekedar untuk memenuhi hasrat } \\
\text { yang muncul }\end{array}$ & - & 0 & 22 & 41 & 36 & 4,10 & Baik \\
\hline & Total & & & & & & 3,97 & Baik \\
\hline
\end{tabular}

Tabel 8. menunjukkan bahwa 3 pernyataan mengenai impulse buying memperoleh nilai rata-rata sebesar 3,97 yang berarti secara umum responden setuju dengan pernyataan - pernyataan yang merupakan indikator dari impulse 
buying. Dengan demikian dapat dikatakan bahwa impulse buyingyang dirasakan responden terhadap produk di Ramayana department store dikategorikan baik, artinya responden sering melakukan pembelian tidak terencana di Ramayana department store.

Data yang ada pada Tabel 8. menunjukkan bahwa nilai rata - rata tertinggi jawaban responden melalui tiga pernyataan ditunjukkan melalui pernyataan"Pada saat melihat barang yang sungguh-sungguh menarik di Ramayana department store, maka akan membelinya seketika, sekedar untuk memenuhi hasrat yang muncul"dengan nilai rata - rata sebesar 4,10. Hal ini berarti responden akan melakukan pembelian impulse saat melihat barang yang sungguh-sungguh menarik di Ramayana department store.

Nilai rata - rata sebesar 4,09 menunjukkan bahwa responden pada saat melihat produk yang cocok di Ramayana department store, tidak berpikir panjang untuk melakukan pembelian. Nilai rata - rata terendah jawaban responden ditunjukkan pada pernyataan "Proporsi pembelian yang tidak direncanakan ke Ramayana department storelebih besar atau sama denganpembelian yang direncanakan" dengan nilai sebesar 3,71 persen.

Tabel 9.

Hasil Uji Normalitas

\begin{tabular}{lc}
\hline & Unstandardized Residual \\
\hline $\mathrm{N}$ & 100 \\
Kolmogorov-Smirnov $Z$ & 0,925 \\
Asymp.Sig.(2-tailed) & 0,360 \\
\hline Sumber : Data diolah, 2018 &
\end{tabular}

Tabel 9. menunjukkan nilai Kolmogorov Smirnov (K-S) sebesar 0,925, sedangkan nilai Asymp. Sig. (2-tailed) sebesar 0,360. Hasil tersebut mengindikasikan bahwa model persamaan regresi tersebut berdistribusi normal karena nilai Asymp. Sig. (2-tailed) lebih besar dari nilai alpha 0,05.

Tabel 10.

Hasil Uji Multikolinearitas

\begin{tabular}{ccc}
\hline Variabel & Tolerance & VIF \\
\hline Visual Merchandising (X1) & 0,399 & 2,506 \\
AtmosferToko (X2) & 0,616 & 1,624 \\
Display Produk (X3) & 0,412 & 2,429 \\
\hline
\end{tabular}
Sumber : Data diolah, 2018

Tabel 10. menunjukkan nilai tolerance dan VIF dari variabel visual merchandising, atmosfertoko, dan display produk menunjukkan nilai tolerance untuk setiap variabel lebih besar dari 10 persen dan nilai VIF lebih kecil dari 10 yang berarti model persamaan regresi bebas dari multikolinearitas. 
Tabel 11.

Hasil Uji Heteroskedastisitas

\begin{tabular}{lcccccc}
\hline & \multicolumn{2}{c}{$\begin{array}{c}\text { Unstandardized } \\
\text { Coefficients }\end{array}$} & $\begin{array}{c}\text { Standardized } \\
\text { Coefficients }\end{array}$ & & \\
\cline { 2 - 4 } Model & B & Std. Error & Beta & & T & Sig. \\
\hline $1 \quad$ (Constant) & .298 & .204 & & & 1.461 & .147 \\
$\quad$ Visual & -.024 & .073 & -.054 & -.335 & .739 \\
$\quad$ Merchandising & & & & & \\
Atmosfer Toko & -.036 & .050 & -.093 & -.720 & .473 \\
$\quad$ Display Produk & .054 & .069 & .124 & .781 & .436 \\
\hline Sumber: Data diolah, 2018 & & & & &
\end{tabular}

Tabel 11. dapat dilihat bahwa nilai signifikansi dari variabel visual merchandising sebesar 0,739 , variabel atmosfer toko sebesar 0,473 , dan variabel display produk sebesar 0,436 . Nilai tersebut lebih besar dari 0,05 yang berarti tidak terdapat pengaruh antara variabel bebas terhadap absolute residual. Sehingga model yang dibuat tidak mengandung gejala heteroskedastisitas.

Model analisis regresi linear berganda digunakan untuk mendapatkan koefisien regresi yang akan menentukan apakah hipotesis yang dibuat akan diterima atau ditolak. Hasil analisis ini mengacu pada hasil pengaruh visual merchandising, atmosfer toko, dan display produk terhadap impulse buying pelanggan Ramayana department storedi Denpasar. Adapun hasil analisis regresi dapat dilihat pada Tabel 12.

Tabel 12.

Hasil AnalisisRegresi Liner Berganda

\begin{tabular}{|c|c|c|c|c|c|}
\hline \multirow[b]{2}{*}{ Model } & \multicolumn{2}{|c|}{$\begin{array}{l}\text { Unstandardized } \\
\text { Coefficients }\end{array}$} & \multirow{2}{*}{$\begin{array}{l}\text { Standardized } \\
\text { Coefficients } \\
\text { Beta } \\
\end{array}$} & \multirow[b]{2}{*}{$\mathbf{T}$} & \multirow[b]{2}{*}{ Sig } \\
\hline & B & Std.Error & & & \\
\hline 1 (Constant) & 0,298 & 0,204 & & 1,461 & 0,147 \\
\hline $\begin{array}{l}\text { Visual } \\
\text { Merchandising }\end{array}$ & $-0,024$ & 0,073 & $-0,054$ & $-0,335$ & 0,739 \\
\hline Atmosfer toko & $-0,036$ & 0,050 & $-0,093$ & $-0,720$ & 0,473 \\
\hline Display product & 0,054 & 0,069 & 0,124 & 0,781 & 0,436 \\
\hline
\end{tabular}

Dimana

$$
\mathrm{Y}=-0,054\left(\mathrm{X}_{1}\right)-0,093\left(\mathrm{X}_{2}\right)+0,124\left(\mathrm{X}_{3}\right)+\varepsilon
$$

$$
\begin{aligned}
& \mathrm{Y}=\text { Impulse Buying } \\
& \mathrm{b} 1, \mathrm{~b} 2, \mathrm{~b} 3=\text { Koefisien beta } \\
& \mathrm{X}_{1}=\text { Visual Merchandising } \\
& \mathrm{X}_{2}=\text { Atmosfer Toko } \\
& \mathrm{X}_{3}=\text { Display Produk } \\
& \varepsilon=\text { error of term }
\end{aligned}
$$

Persamaan regresi linear berganda tersebut memperlihatkan arah masingmasing variabel bebas terhadap variabel terikatnya, penjelasan persamaan regresi penelitian ini adlaah nilai koefisien beta visual merchanding sebesar 0,054memiliki nilai yang negatif menunjukkan adanya hubungan yang tidak 
searah, apabila visual merchanding naik sebesar satu persen, maka impulse buying turun sebesar 0,054 satuan dengan syarat variabel bebas lainnya konstan atau sama dengan nol.

Nilai koefisien beta atmosfer toko sebesar $-0,093$ memiliki nilai yang negatif menunjukkan adanya hubungan yang tidak searah, apabila atmosfer tokonaik sebesar satu persen, maka impulse buying turun sebesar 0,093 satuan dengan syarat variabel bebas lainnya konstan atau sama dengan nol.Nilai koefisien beta display produk sebesar 0,124 memiliki nilai yang positif menunjukkan adanya hubungan yang searah, apabila display produknaik sebesar satu persen, maka impulse buying meningkat sebesar 0,124 satuan dengan syarat variabel bebas lainnya konstan atau sama dengan nol.

Tabel 13.

Hasil Uji Kelayakan Model

\begin{tabular}{|c|c|c|c|c|c|}
\hline Modal & $\begin{array}{c}\text { Sum of } \\
\text { Squares }\end{array}$ & Df & $\begin{array}{c}\text { Mean } \\
\text { Square }\end{array}$ & $\mathbf{F}$ & Sig \\
\hline 1 Regression & 0,059 & 3 & 0,020 & 0,312 & $0,817^{\mathrm{a}}$ \\
\hline Residual & 6,058 & 96 & 0,063 & & \\
\hline Total & 6,117 & 99 & & & \\
\hline
\end{tabular}

Sumber: Data diolah, 2018

Tabel 13. menunjukkan nilai $\mathrm{F}$ hitung sebesar 0,312 dengan signifikansi 0,817 yang probabilitas signifikansi lebih besar dari alpha 0,05 . Ini menunjukkan bahwa variabel visual merchandising, atmosfer toko, dan display produktidak dapat digunakanuntuk memprediksi impulse buying, atau dapat dikatakan bahwa variabel visual merchandising, atmosfer toko, dan display produk secara bersamasama tidak berpengaruh terhadap impulse buying.

Uji kelayakan model (uji f) dilakukan untuk mengetahui dan menguji pengaruh variabel bebas (visualmerchandising, atmosfer toko, display produk secara bersama-sama mempunyai pengaruh yang nyata atau signifikan terhadap variabel terikat (impulsebuying). Jika hasil menunjukan tingkat signifikansi $\mathrm{F}$ probabilitas lebih kecil dari 0,05, maka dapat disimpulkanbahwa model regresi layak digunakan untuk memprediksi variabel terikat, namun apabila probabilitas lebih besar dari 0,05 maka variabel bebas memiliki pengaruh terhadap variabel terikat.

Tabel 14.

Hasil Uji Koefisien Determinasi

\begin{tabular}{ccccc}
\hline Model & R & R Square & $\begin{array}{c}\text { Adjusted R } \\
\text { Square }\end{array}$ & $\begin{array}{c}\text { Std. Error of } \\
\text { the Estimate }\end{array}$ \\
\hline 1 & $0,098^{\text {a }}$ & 0,010 & $-0,021$ & 0,25122 \\
\hline Sumber: Data diolah 2018 & & &
\end{tabular}

Sumber: Data diolah, 2018

Tabel 14. menunjukkan koefisien determinasi dilihat melalui nilai R Square $\left(\mathrm{R}^{2}\right)$. Adapun nilai dari $\mathrm{R}^{2}$ pada penelitian ini telah disajikan pada Tabel 14. dapat dilihat bahwa nilai Adjusted $\mathrm{R}^{2}=0,10$, yang berarti bahwa sebesar 10 persen impulse buying pelanggan Ramayana department store di Denpasar dipengaruhi oleh variabel visual merchandising, atmosfer toko, dan display produk, sedangkan 
sisanya sebesar 90 persen dipengaruhi oleh variabel lain diluarmodel regresi yang digunakan.

Uji hipotesis (uji t) digunakan untuk mengetahui dan menguji apakah ada pengaruh nyata atau signifikan secara individu antara variabel bebas terhadap kinerja karyawan. Tingkat signifikansi yang digunakan sebesar 0,05 atau 5 persen.Pengujian hitung lebih besar daripada t tabel, maka Hi diterima sedangkan Ho ditolak, dan sebaliknya apabila pada pengujian didapatkan hasil bahwa t hitung lebih kecil daripada t table maka Ho diterima dan Hi ditolak

Tabel 15.

Hasil Uji T

\begin{tabular}{|c|c|c|c|c|c|}
\hline \multirow[b]{2}{*}{ Model } & \multicolumn{2}{|c|}{$\begin{array}{l}\text { Unstandardized } \\
\text { Coefficients }\end{array}$} & \multirow{2}{*}{$\begin{array}{l}\begin{array}{l}\text { Standardized } \\
\text { Coefficients }\end{array} \\
\text { Beta } \\
\end{array}$} & \multirow[b]{2}{*}{$\mathbf{T}$} & \multirow[b]{2}{*}{ Sig } \\
\hline & B & Std.Error & & & \\
\hline 1 (Constant) & 0,298 & 0,204 & & 1,461 & 0,147 \\
\hline $\begin{array}{l}\text { Visual } \\
\text { Merchandising }\end{array}$ & $-0,024$ & 0,073 & $-0,054$ & $-0,335$ & 0,739 \\
\hline Atmosfer toko & $-0,036$ & 0,050 & $-0,093$ & $-0,720$ & 0,473 \\
\hline Display product & 0,054 & 0,069 & 0,124 & 0,781 & 0,436 \\
\hline
\end{tabular}

Sumber: Data diolah, 2018

Berdasarkan Tabel 15. dapat dijelaskan Pengaruh visual merchandising $\left(\mathrm{X}_{1}\right)$ terhadap impulse buying (Y)diperoleh nilai signifikansi uji t dari variabel visual merchandisingsebesar 0,739 , nilai signifikansi uji t sebesar 0,739>0,05 maka $\mathrm{H}_{0}$ diterima, ini berarti bahwa visual merchandisingtidak berpengaruh signifikan terhadap impulse buying. Koefisien regresi $\mathrm{X}_{1}$ sebesar $-0,335$, menunjukkan bahwa meningkatnya visual merchandisingtidak akan meningkatkan impulse buying pelanggan Ramayana department storedi Denpasar.

Pengaruh atmosfer toko $\left(\mathrm{X}_{2}\right)$ terhadap impulse buying $(\mathrm{Y})$ diperoleh nilai signifikansi uji t dari variabel atmosfer toko sebesar 0,473 , nilai signifikansi uji t sebesar 0,473 >0,05 maka $\mathrm{H}_{0}$ diterima, ini berarti bahwa atmosfer toko tidak berpengaruh signifikan terhadap impulse buying. Koefisien regresi $\mathrm{X}_{2}$ sebesar 0,720, menunjukkan bahwa meningkatnya atmosfer toko tidak akan meningkatkan impulse buying pelanggan Ramayana department storedi Denpasar.

Pengaruh displayproduk $\left(\mathrm{X}_{3}\right)$ terhadap impulse buying (Y)diperoleh nilai signifikansi uji t dari variabel displayproduksebesar 0,436, nilai signifikansi uji t sebesar 0,436 >0,05 maka $\mathrm{H}_{0}$ diterima, ini berarti bahwa displayproduktidak berpengaruh signifikan terhadap impulse buying. Koefisien regresi $\mathrm{X}_{3}$ sebesar 0,781, menunjukkan bahwa meningkatnya display produk maka akan meningkatkan pulaimpulse buying namun tidak signifikan terhadap pelanggan Ramayana department storedi Denpasar.

Penelitian ini menemukan hasil bahwa visual merchandising berpengaruh negatif dan tidaksignifikan terhadap impulse buyingpelanggan Ramayana department store di Denpasar yang berarti semakin baik kegiatan visual merchandising pada Ramayana department store di Denpasar tidak dapat meningkatkan impulse buying pada pelanggan Ramayana department store di Denpasar.Visual merchandising berperan dalam menambahkan informasi untuk 
barang dagangan, melengkapi barang dagangan tertentu, dan membangun strategi pengiriman pesan melalui gambar yang kemudia mendorong konsumen untuk melakukan pembelian impulse (Kim, 2013).Hasil penelitian ini tidak mendukung penelitian sebelumnya yang dilakukan oleh Prasad and Dr. SC Vetrivel (2016), Hadjali et al. (2012), Rathee \& Prakash (2017), Sari dan Alit Suryani (2017), memperlihatkan bahwa kegiatan visual merchandising yang dilakukanperitel dapat meningkatkan impulse buyingpada perusahaan ritel.

Penelitian ini menemukan hasil bahwa atmosfer toko berpengaruh negatif dan tidak signifikan terhadap impulse buyingpelanggan Ramayana department store di Denpasar yang berarti semakin baik penciptaan atmosfer toko oleh pihak Ramayana department store di Denpasar tidakmampu meningkatkan impulse buying pada pelanggan Ramayana department store di Denpasar.Atmosfer tokoyang nyaman menjadi bahan pertimbangan tersediribagi konsumen sebelum memutuskan untukdatang atau mengunjungi gerai tertentu(Meldarianda, 2010).

Hasil penelitian ini tidaksejalan dengan penelitian sebelumnya yang dilakukan oleh Yistiani et al. (2012), Pancaningrum (2017),Pemayun \& Ekawati (2016) memperlihatkan bahwaatmosfer toko dapat meningkatkan impulse buyingsecara signifikan pada Hardy's Mall Gatsu Denpasar.Penelitian ini menemukan hasil bahwa display produkberpengaruh positif namun tidaksignifikan terhadap impulse buyingpelanggan Ramayana department store di Denpasar yang berarti semakin baik pengaturan display produkpada Ramayana department store di Denpasar maka dapat meningkatkan impulse buying pada pelanggan Ramayana department store di Denpasar.Displayproduk dianggap sebagai alat pemasaran yang kuat dan merukapakan bagian dari Point of Purchase Stimuli (POP Stimuli) untuk memotivasi konsumen dalam membeli produk dengan dorongan impulse (Sarma, 2014). Hasil penelitian ini sesuai dengan penelitian sebelumnya yang dilakukan oleh Rahmadana (2016) yang menjelaskan bahwa variabel display produk secara parsial tidak berpengaruh signifikan terhadap keputusan pembelian impulse di Minimarket Eramart cabang Lembuswana Samarinda.

Hasil penelitian ini menyatakan bahwa visual merchandising, atmosfer toko, dan display produk memiliki pengaruh tidak signifikan terhadap impulse buying. Pemahaman akan adanya pembelian impulsedan variabel-variabel yang mendukung terjadinya pembelian impulse ini memberikan pengaruh positif bagi pihak Ramayana department store guna meraup pasar sasaran dan meningkatkn omzet penjualan perusahaan. Hal ini menunjukkan bahwa perlu pengkajian terhadap variabel lain untuk meningkatkan potensi impulse buying pelanggan Ramayana department store di Denpasar.

Responden selaku pelanggan menyatakan ketersediaan jenis produk yang lengkap dan sesuai trend,pemajangan tulisan harga dan diskon yang jelas, dankerapian dalam penataan letak produk yang diterapkan pihak Ramayana department store dapat memudahkan pelanggan dalam melakukan pembelian produk yang diinginkan. Pihak Ramayana department store hendaknya mempertahankan kebijakan mengenai ketersediaan jenis produk yang lengkap dan sesuai trend,pemajangan tulisan harga dan diskon yang jelas, dankerapian dalam 
penataan letak produk yang telah diterapkan karena terbukti membuat pelanggan merasa puas dan senang berbelanja di Ramayana department store.

\section{SIMPULAN}

Berdasarkan hasil pembahasan penelitian yang telah dilakukan, maka dapat disimpulkan bahwa visual merchandising berpengaruh negatif dan tidak signifikan terhadap impulse buying pelanggan Ramayana department store di Denpasar yang berarti semakin baik kegiatan visual merchandising pada Ramayana department store di Denpasar tidak dapat meningkatkan impulse buying pada pelanggan Ramayana department store di Denpasar.Atmosfer toko berpengaruh negatif dan tidak signifikan terhadap impulse buying pelanggan Ramayana department store di Denpasar yang berarti semakin baik penciptaan atmosfer toko oleh pihak Ramayana department store di Denpasar tidak mampu meningkatkan impulse buying pada pelanggan Ramayana department store di Denpasar.

Display produkberpengaruh positif namun tidak signifikan terhadap impulse buying pelanggan Ramayana department store di Denpasar yang berarti semakin baik pengaturan display produkpada Ramayana department store di Denpasar maka dapat meningkatkan impulse buying pada pelanggan Ramayana department store di Denpasar.

Saran yang dapat diberikan pada penelitian ini adalah Pihak Ramayana department store hendaknya mempertahankan kebijakan mengenai ketersediaan jenis produk yang lengkap dan sesuai trend,pemajangan tulisan harga dan diskon yang jelas, dankerapian dalam penataan letak produk yang telah diterapkan karena terbukti membuat pelanggan merasa puas dan senang berbelanja di Ramayana department store.

\section{REFERENSI}

Abdolvand, Mohamad Ali., Kambiz Heidarzadeh Hanzaee., Afshin Rahnama., and K. (2011). The Effect of Situasional and Individual Factors on Impulse Buying. World Applied Sciences Journal, 13(9), 2108-2117.

Ahad, N., Tanveer, N., Ali, T., \& Khanum, Z. (2015). Impulse buying behavior and its influential factors. Scholars Journal of Economics, Business and Management, 2(7A), 703-706.

Ajzen, Icek, \& Fishbein., M. (2005). The influence of attitudes on behaviour. Https://Pdfs.Semanticscholar.Org/2779/Def3b6e5ff2a03baa06f9b70c42cfe7 Od95b.Pdf.

Astuti, R. D., \& Fillippa, M. (2008). Perbedaan Pembelian Secara Impulsive Berdasarkan Tingkat Kecenderungan, Kategori Produk Dan Pertimbangan Pembelian. Jurnal Ichsan Gorontalo, 3(1), 1441-1456.

Alma, B. 2014. Manajemen Pemasaran Dan Pemasaran Jasa. Bandung: Cv Alfabeta. 
BaliTribunnews. Badung Kota Terpadat. http://bali.tribunnews.com/2015/ 02/05/denpasardanbadungjadikotaterpadatkendaraan. Diakses 8 Desember 2018.

Bayley, G., \& Nancarrow, C. (1998). Impulse purchasing: a qualitative exploration of the phenomenon, 1(2), 99-114.

Bhalla, S. and Anuraag, S. (2010). Visual merchandising. New Delhi: McGraw Hill.

Choudhary, S. (2014). Study of Impulse Buying Behavior of Consumers. International Journal of Advance Research in Computer Science and Management Studies, 2(9), 1-4.

Christina Whidya Utami. (2010). Manajemen Ritel: Strategi dan ImplementasiOperasional Bisnis Ritel Modern di Indonesia. Edisi ke 2. Jakarta:Salemba Empat.

Das, S. P., \& Das, S. S. (2015). The International Journal Of Business \& Management The Importance of Visual Merchandising on Customer Loyalty, a Study Conducted in Kolkata Abstract : The International Journal of Business \& Management, 3(5), 195-203.

Gillani, M. F. (2012). Impact of Peer Pressure and Store Atmosphere on Purchase Intention: An Empirical Study on the Youngsters in Pakistan. International Journal of Academic Resaerch in Business and Social Sciences, 2(7), 323332.

Hadjali, H. R., Salimi., M., \& Ardestanis, M. S. (2012). Exploring Main Factors Affecting on Impulse Buying Behaviours. Journal of American Science, $8(1), 245-251$.

Hussain, R., \& Ali, M. (2015). Effect of Store Atmosphere on Consumer Purchase Intention. International Journal of Marketing Studies, 7(2), 35-43. https://doi.org/10.5539/ijms.v7n2p35

Jain, V., Sharma, A., \& Narwal, P. (2012). Impact of Visual Merchandising on Consumer Behavior towards Women's Apparel. International Journal of Research in Management, 5(2), 106-117.

Kacen, J. J., \& Lee, J. A. (2012). The Influence of Culture on Consumer Impulsive Buying Behavior. Journal of Consumer Psychology, 12(2), 163176. https://doi.org/10.1207/s15327663jcp1202_08

Khorrami, M. S., Esfidani, M. R., \& Delavari, S. (2015). The Effect of Situational 
Factors on Impulse Buying and Compulsive Buying: Clothing. International Journal of Management, Accounting and Economics, 2(28), 823-837. Retrieved from www.ijmae.com

Kim, J. S. (2013). A study on the effect that V.M.D (Visual Merchandising Design) in store has on purchasing products. International Journal of Smart Home, 7(4), 217-224.

Kotler, Philip dan Gary Amstrong. 2008. Prinsip-Prinsip Pemasaran, Alih Bahasa Damos Sihombing. Jilid 1. Erlangga, Jakarta.

Kotler, P. and Keller, K.L. 2016. Marketing Management Global Edition. 15th Edition. Edinburg Gate Harlow England. Pearson Education.

Levy M. and Weitz B.A. 2007. Retailing Manajement. 6th Edition.

Ma'ruf, H. 2006. Pemasaran Ritel. Jakarta. PT.Gramedia Pustaka Utama.

Maymand, M. M., \& Ahmadinejad, M. (2011). Impulse Buying: The Role of Store Environmental Stimulation and SituationalFactors (An empirical investigation). African Journal of Business Management,5(34), 1305713065.

Muthiah, I., Parawansa, D. A. ., \& Munir, A. R. (2018). Pengaruh Visual Merchandising , Display Product, Dan Store Atmosphere Terhadap Perilaku Impulse Buying ( Studi Kasus : Konsumen Matahari Department Store Di Kota Makassar ) the Effect of Visual Merchandising, Product Display Dan Store Atmosphere on Impu. Hasanuddin Journal of Applied Business and Entrepreneurship, 1, 88-103.

Pancaningrum, E. (2017). Visual Merchandise Dan Atmosfer Toko : Pengaruhnya Terhadap Keputusan Pembelian. Jiep, 17(1), 23-40.

Pemayun, T. I. D. P., \& Ekawati, N. W. (2016). Pengaruh Promosi, Atmosfer Gerai, dan Merchandise Terhadap Pembelian Impulsif Pada Hardy's Mall Gatsu Denpasar. E-Jurnal Manajemen Unud, 5(7), 4132-4160.

Prasad, K. A., \& Vetrivel, S. C. (2016). " An Empirical Study on Visual Merchandising and Its Impact on Consumer Buying Behaviour ," 18(11), 814. https://doi.org/10.9790/487X-1811020814

Rahmadana, N. M. S. (2016). Pengaruh Display Produk dan Suasana Toko Terhadap Pembelian Impulsif di Minimarket Eramart Cabang Lembuswana Samarinda. EJournal Ilmu Administrasi Bisnis, 4(3), 683-697.

Rathee, V., \& Prakash, C. (2017). Influence of Visual Merchandising on 
Customer Buying Decision- A Review of Literature Approach. International Journal Peer Reviewed Journal Refereed Journal Indexed Journal UGC Approved Journal. Impact Factor MJIF, 12. https://doi.org/10.19030/iber.v12i10.8132

Sari, D. A. T., \& Suryani, A. (2008). Pengaruh Merchandising , Promosi dan Atmosfir Toko Terhadap Impulse Buying. E-Jurnal Manajemen Universitas Udayana, 851-867.

Sarma, S. (2014). A study of Retail Display and Impulse Buying Behavior. Journal of Marketing and Consumer Research, 4(1), 51-55. Retrieved from http://iiste.org/Journals/index.php/JMCR/article/view/12069

Soeseno Bong, P. (2011). Pengaruh In-Store Stimuli Terhadap Impulse Buying Behaviour Konsumen Hypermarket di Jakarta. Jurnal Ultima Management, 3(1), 31-52.

Sugiyono, (2013). Metode Penelitian Kuantitatif, Kualitatif dan RdanB, Bandung: Alfabeta.

Suprapti, Ni Wayan Sri. (2010). Prilaku Konsumen, Pemahaman Dasar dan Aplikasinya Dalam Strategi Pemasaran.Bali : Udayana University Press.

Thomas, A. K. (2018). The Impact of Visual Merchandising, on Impulse Buying Behavior of Retail Customers. International Journal for Research in Applied Science and Engineering Technology, 6(2), 474-491. https://doi.org/10.22214/ijraset.2018.2069

Tom, E. (2015). Impulse Buying Behaviour and Demographic Analysis among University of Calabar Students, Nigeria. Journal of Marketing and Consumer Research, 17, 42-48.

Yistiani, N. N. manik, Yasa, N. N. K. Y., \& Suasana, I. G. . K. G. (2012). Pengaruh Atmosfer Gerai dan Pelayanan Ritel Terhadap Nilai Hedonik dan Pembelian Impulsif Pelanggan Matahari Department Store Duta Plaza di Denpasar. Manajemen Strategi Bisnis Dan Kewirausahaan, 6(2), 139-149. https://doi.org/10.1186/s12967-017-1232-6 